\title{
Studies on the Light Affecting the Initiation of Endogenous Rhythms Concerned with Photoperiodic Responses in Pharbitis nil
}

\author{
by Atsushi TAKimoto*
}

Received February 16, 1967

\begin{abstract}
Two endogenous rhythms, light-on and light-off rhythms, are associated with the photoperiodic floral response of Pharbitis nil 1,22 . The light conditions required to initiate or reset these rhythms were investigated.

Two hours of light at 4000 lux was not enough to initiate its own rhythm when applied 8 hours after the beginning of the dark period; i. e. the light-off rhythm initiated at the beginning of the preliminary 8-hour dark period still persisted after the 2-hour light period. Light periods of 4 to 8 hours were sufficient to initiate a new rhythm even at 10-70 lux.

The light-off rhythm was initiated when plants were transferred from 4000 lux to 10 lux and proceeded normally under 10 lux. Transfer of plants from 4000 lux to 250 lux did not initiate the light-off rhythm, but transfer from 250 lux to darkness was effective.

Spectral dependence of light required to initiate the light-off and/or light-on rhythms was very similar to that for light break and the reversion of the far-red effect. Blue, green, red, and white light of $1000,30,12$, and $30 \mu \mathrm{w} / \mathrm{cm}^{2}$, respectively, were equally effective for induction of the light-off and/or light-on rhythms.
\end{abstract}

As has been shown in previous papers ${ }^{1,2)}$, two endogenous rhythms are associated with the photoperiodic response of Pharbitis nil; One is initiated by the beginning of the light period (the light-on rhythm) and the other is initiated by the beginning of the dark period (the light-off rhythm). The former is shown as a stepwise increase in the flowering responses progressing with increasing length of the dark period, and the latter as a rhythmic response to red light interruption, i. e. it has red sensitive phases with maxima 8 and 32 hours after the onset of darkness. A brief period of illumination gives the plant both a light-on and a light-off signal. An illumination of two hours or less (4000 lux), however, is not enough to initiate its own rhythms when applied during the dark period out of phase with the rhythms which had been induced by prior treatment ${ }^{1,2)}$, i. e. the light-off rhythm initiated at the beginning of the preliminary dark period still persists after the 2-hour light period. A light period of 4 hours (4000lux) was sufficient to reset the preinduced rhythm ${ }^{1)}$. The question arises as to whether or not the intensity or color of light affects the intensity and effectiveness of the rhythms produced. Is transfer of the plants from light to complete darkness, or from complete darkness to light, required to initiate the rhythms? If not, how much change in light intensity is required to initiate the light-on or light-off rhythm ?

* Laboratory of Applied Botany, Faculty of Agriculture, Kyoto University, Kyoto, Japan. 


\section{Material and Methods}

Seedlings of Pharbitis nil, strain Violet, were used for all experiments. Experimental methods and procedures were similar to those described previously ${ }^{3)}$. The light sources and filters used were also described there.

\section{Experimental Results and Discussion}

Experiment 1: Plants grown under continuous illumination for 4 days were given 8 hours of darkness followed by 4 or 8 hours of white light of different intensities. Plants were then kept in darkness for 48 hours at $21^{\circ}$ and exposed to
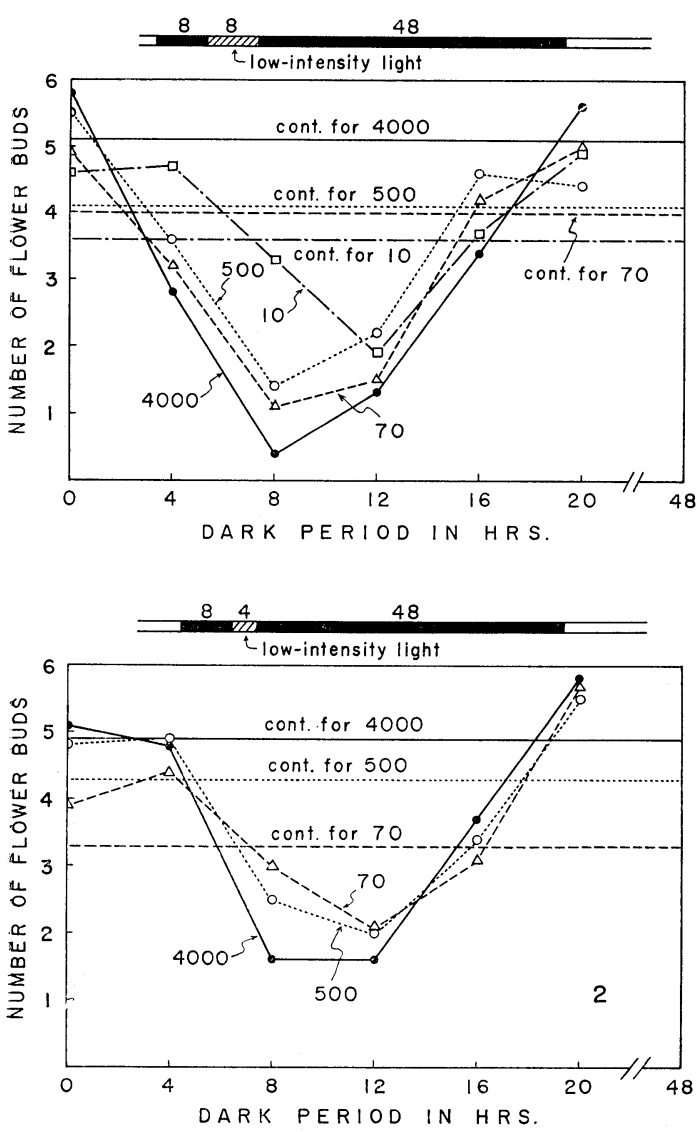

Fig. 1. Flowering responses to red light interruption ( $300 \mu \mathrm{w} / \mathrm{cm}^{2}$ for $15 \mathrm{~min}$.) applied at different times during the 48-hour dark period which was preceded by an 8-hour dark period and an 8-hour period of low-intensity light of 10 , 70,500 , or 4000 lux.

Fig. 2. Similar to Fig. 1, but the light period preceding 48 -hour period was 4 hours.
15 minutes of red light $\left(300 \mu \mathrm{w} / \mathrm{cm}^{2}\right)$ at different times. Results are shown in Figs. 1 and 2. Plants exposed to 70, 500, and 4000 lux showed similar responses to red light interruptions, i. e. the red light interruption given 8 hours after the beginning of the 48-hour dark period was most inhibitory. This implies that the light-off rhythm was initiated at the beginning of the 48hour dark period, and the as little as 70 lux of white light can interfere with the preinduced rhythm and initiate its own light-off rhythm. Since this amount of light is less than that required for ordinary photosynthesis, the photosynthate supply probably does not significantly influence the initiation of an endogenous rhythm. The initiation of an endogenous rhythm may be influenced more by the duration of illumination than by the total amount of light received.

When the light intensity was reduced to 10 lux and given for 8 hours, the flowering response to red light interruptions differed significantly from the other response curves (Fig. 1). The maximum inhibition occurred at the 12th hour point, red light given at the 8-hour point having little effect. This suggests that the low-intensity light of 10 lux given for 8 hours after an 8-hour dark period is enough to initiate its own light-on rhythm which has the 
most inhibitory phase 20 hours after the onset of the light period ${ }^{1)}(12$ hours after the beginning of the dark period in this experiment), but is not enough to initiate a light-off rhythm which has the most inhibitory phase 8 hours after the onset of darkness.

When the light period was 4 hours (Fig. 2), maximum inhibition by red light interruption was obtained at the 12th hour rather than the 8th hour with all light intensities. As has been reported previously ${ }^{1,2)}$, the time of effectiveness of the red light interruption is delayed and extended as the light preceding the dark period decreases. This phenomenon was interpreted assuming that the light-on rhythm was initiated at the beginning of the light period, and, together with the light-off rhythm, influenced the time of effectiveness of the red light interruption.

Experiment 2: Seedlings grown under continuous illumination of 4000 lux were exposed to 10, 50, 250, or 1000 lux of white light for 8 hours, followed by a 40-hour dark period $\left(20^{\circ}\right)$. Fifteen minutes of red light $\left(300 \mu \mathrm{w} / \mathrm{cm}^{2}\right)$ was given at different times during illumination with low-intensity light and during the dark period. As shown in Fig. 3, when the intensity of white light during the 8-hour light period was 10 lux, red light was most inhibitory when given at the beginning of the dark period. When the intensity of white light was 250 lux or higher, red light was most inhibitory when given 8 hours after the beginning of the dark period. This implies that the light-off rhythm was initiated when plants were transferred from 4000 lux to 10 lux and proceeded normally under 10 lux. Transfer from 4000 lux to 250 lux was not enought to initiate the light-off rhythm although transfer from 250 lux to darkness was effective. When the intensity of white light was 50 lux, flowering was strongly inhibited (see control level) and a red interruption given 4 hours after the beginning of the dark period was most inhibitory. The oscillation of the light-off rhythm was greatly disturbed by this treatment. A strong oscillation of the lightoff rhythm may be necessary for optimal flowering.

The light-off rhythm is considered to have a decisive role determining the critical dark period ${ }^{4}$. This rhythm is initiated when plants are transferred from highintensity light to 10 lux and proceeds normally under 10 lux. Therefore, when a dark period is preceded by 4 - or 8-hour low-intensity light of 10 lux, the critical dark period may be shortened by some 4 or 8 hours, respectively. Such was the case in our previous experiments reported ${ }^{5,6,7)}$.

Experiment 3: Seedlings grown under continuous illumination were subjected to an 8-hour dark period, 8 hours of colored light at different intensities, and then 48 hours of darkness at $21^{\circ}$. During the first half of the 48 -hour dark period, plants were exposed to 15 minutes of red light $\left(300 \mu \mathrm{w} / \mathrm{cm}^{2}\right)$ at different times. The results are shown in Figs. 4-7. Maximum inhibition of flowering is seen when the 
red light interruption was given 8 hours after the beginning of the 48-hour dark period provided the intensity of blue, green, or red light was 1000,20 , or $10 \mu \mathrm{w} / \mathrm{cm}^{2}$, respectively, or higher. This suggests that, for each spectral region, these intensities, but not lower intensities, are enough to initiate their own light-off rhythms. Even $1500 \mu \mathrm{w} / \mathrm{cm}^{2}$ of far-red light was not enough to produce such a rhythmic response to red light interruption (Fig. 7). White light of 70 lux $\left(\fallingdotseq 30 \mu \mathrm{w} / \mathrm{cm}^{2}\right)$, but not 10 lux $\left(\fallingdotseq 4 \mu \mathrm{w} / \mathrm{cm}^{2}\right)$, was enough to induce the light-off rhythm in Experiment 1 . The minimum intensity for each color of light required to initiate the light-off rhythm is therefore $320-1000 \mu \mathrm{w} / \mathrm{cm}^{2}$ in blue, $5-20 \mu \mathrm{w} / \mathrm{cm}^{2}$ in green, $1.5-10 \mu \mathrm{w} / \mathrm{cm}^{2}$ in red, and $4-30 \mu \mathrm{w} / \mathrm{cm}^{2}$ in white light. If the relative intensity of blue, green, red, and white is $1000: 30: 12: 30$, each region of the spectrum exerts the same effect for both light break and the reversion of the far-red effect ${ }^{3}$. Spectral dependence of the light necessary to initiate the light-off rhythm is therefore very similar to that for light break or reversion of the far-red effect, thus suggesting that the same or similar pigments are associated with all of these reactions.

Blue and far-red lights were very inhibitory to flowering (see control level in Figs. 4 and 7), and the inhibitory effect increased with increasing intensity. This inhibition was overcome by red light given at the beginning of the dark period. Blue light at high intensities was effective in initiating the light-off rhythm, but far-red was not.
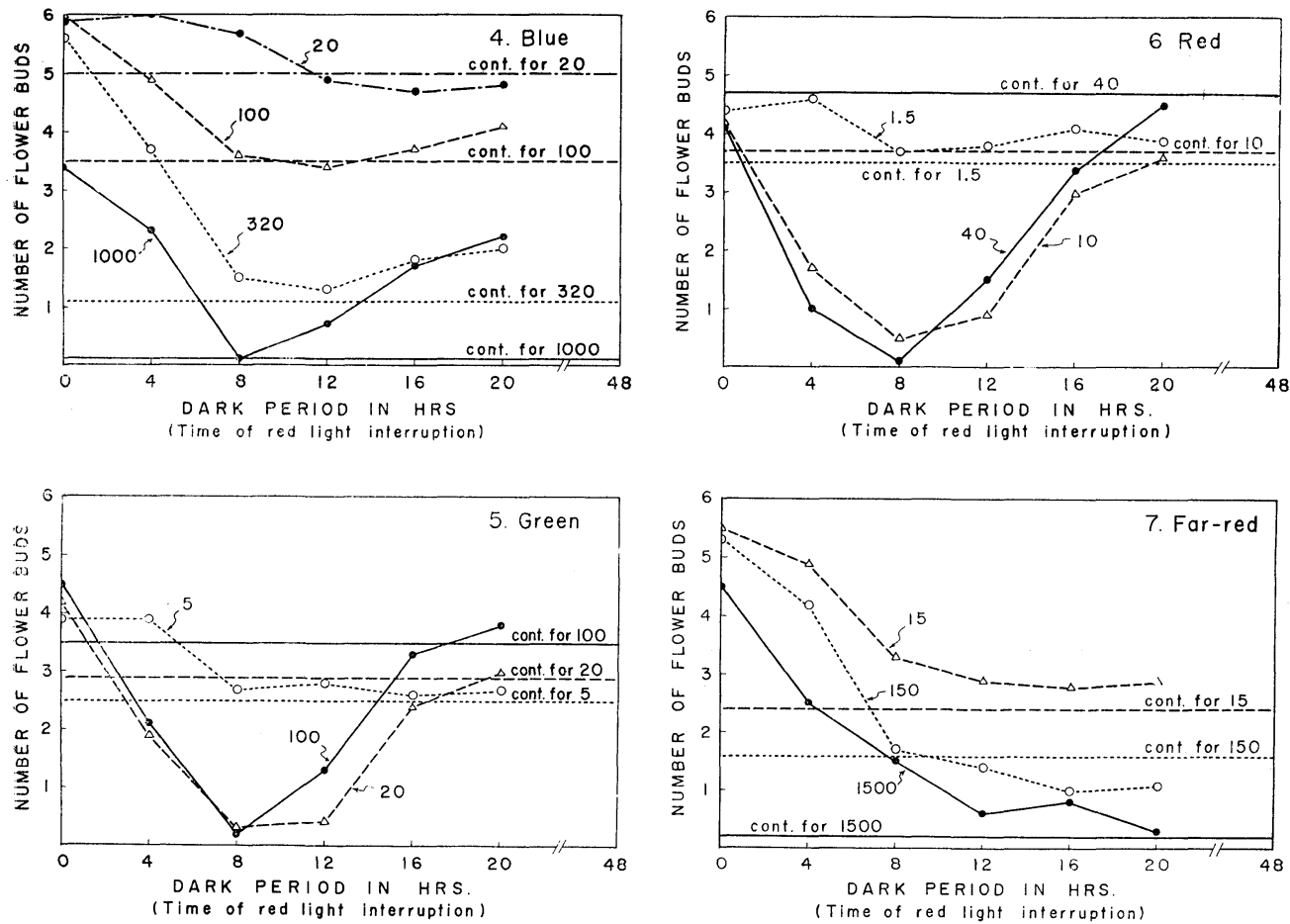

Figs. 4-7. Flowering responses to red light interruption (300 $\mu \mathrm{w} / \mathrm{cm}^{2}$ for $15 \mathrm{~min}$.) applied at different times during the 48 -hour dark period $\left(21^{\circ}\right)$ which was preceded by an 8-hour dark period and 8 hours of colored light of different intensities. Fig. 4: Blue, Fig. 5: Green, Fig. 6: Red, Fig. 7: Far-red light. Figures adjacent to each curve show the intensity of light in $\mu \mathrm{w} / \mathrm{cm}^{2}$. 
Experiment 4: Seedlings grown under continuous illumination of 4000 lux from daylight fluorescent lamps were exposed to various intensities of colored light for 8 hours followed by a 40 -hour dark period at $20^{\circ}$. During the period of colored light and the dark period, plants were exposed to 15 minutes of red light at different times. Results presented in Figs. 8-11 show that when the intensity of blue, green, and red light was 20,5 , and $1.5 \mu \mathrm{w} / \mathrm{cm}^{2}$, respectively, the red light interruption given at the beginning of the dark period was most inhibitory, i. e. the light-off rhythm was initiated at the beginning of these colored light treatments and persisted under these colored lights. When the intensity of blue, green, and red was 1000,100 , and $40 \mu \mathrm{w} /$ $\mathrm{cm}^{2}$, respectively, or higher, the red light interruption was most inhibitory when given 8 hours after the beginning of the dark period, i. e. the light-off rhythm was initiated at the beginning of the dark period. It is interesting that the low-intensity light given preceding an inductive dark period was most inhibitory when the intensity was between the two levels mentioned above, and at these intensities the light-off rhythm was greatly disturbed.

Blue and far-red lights were very inhibitory to flowering, but the inhibitory effects were overcome by giving a red light interruption, provided that the time of red irradiation did not fall in an inhibitory phase of the light-off rhythm produced. Blue light at a high intensity was effective in initiating a light-off rhythm when followed by a dark period (Fig. 8), but far-red was not (Fig. 11).

Experiment 5: A previous paper ${ }^{3)}$ showed that the blue, green, red, and white lights have a similar effect when used for interruptions (light break) of the dark
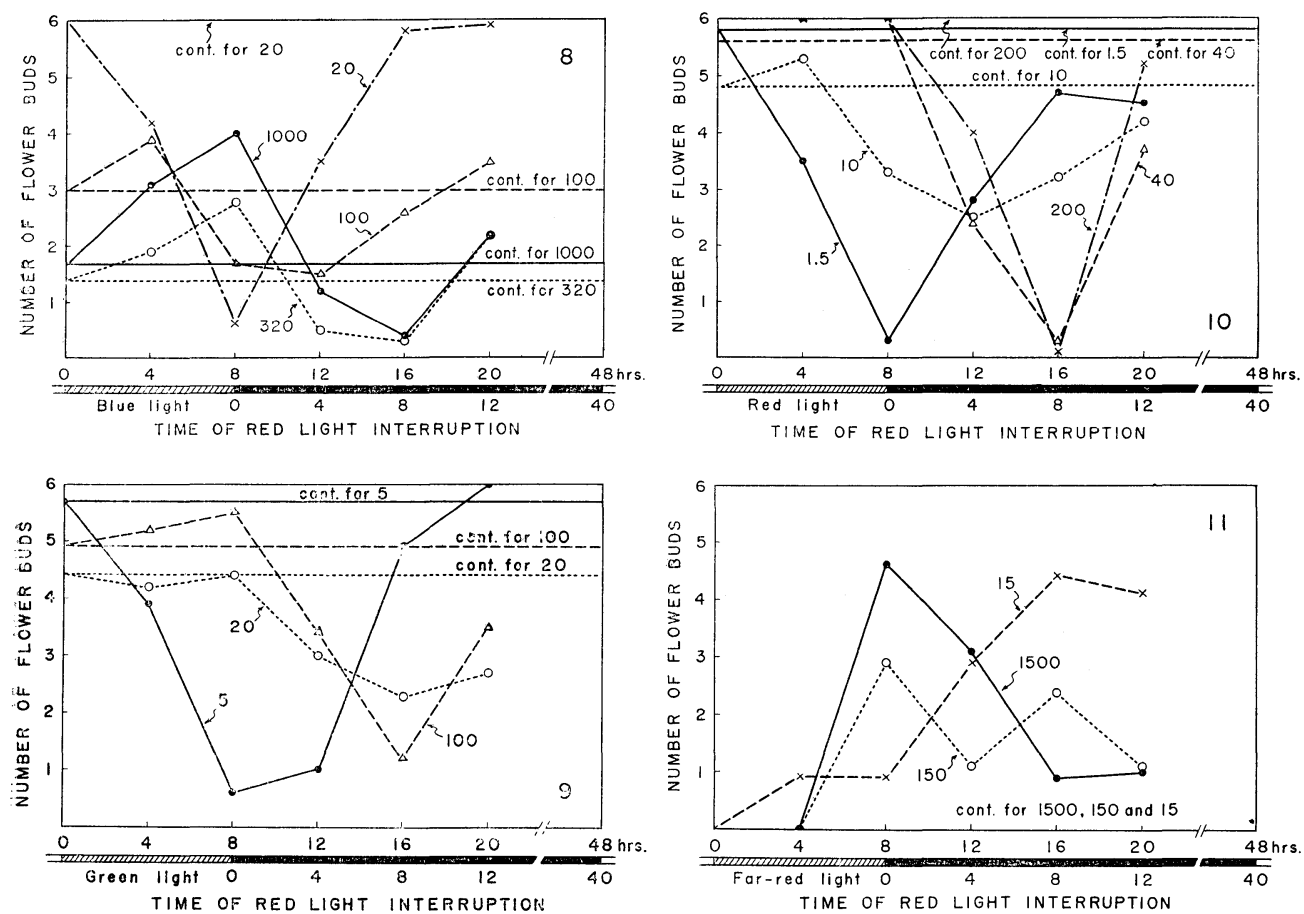

Figs. 8-11. Flowering responses to red light interruption ( $300 \mu \mathrm{w} / \mathrm{cm}^{2}$ for 15 minutes) given during the 8 hours of colored light of different intensities and the subsequent 40 . hour dark period $\left(20^{\circ} \mathrm{C}\right)$. Fig. 8: Blue, Fig. 9: Green, Fig. 10: Red, Fig. 11: Far-red. 


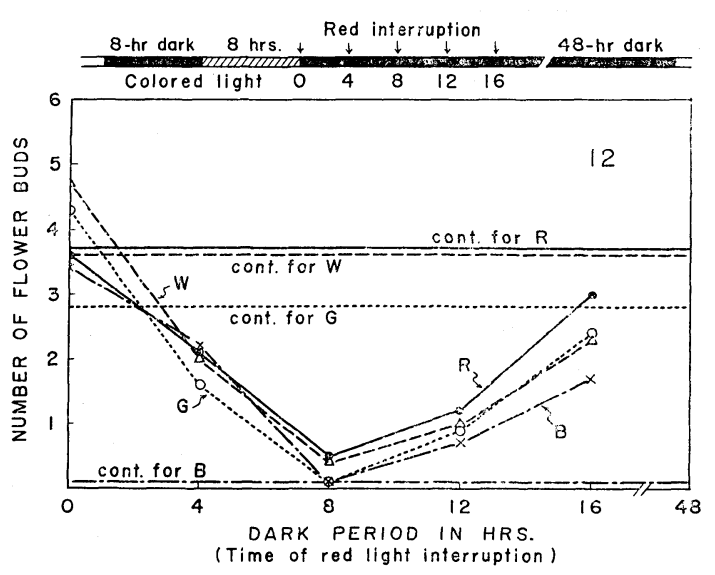

Fig. 12. Flowering responses to red light interruption applied at different times during a 48-hour dark period $\left(21^{\circ}\right)$ which was preceded by an 8 -hour dark period and 8 hours of blue $\left(1000 \mu \mathrm{w} / \mathrm{cm}^{2}\right)$, green $\left(30 \mu \mathrm{w} / \mathrm{cm}^{2}\right)$, red $(12 \mu \mathrm{w} /$ $\left.\mathrm{cm}^{2}\right)$, or white $\left(30 \mu \mathrm{w} / \mathrm{cm}^{2}\right)$ light.

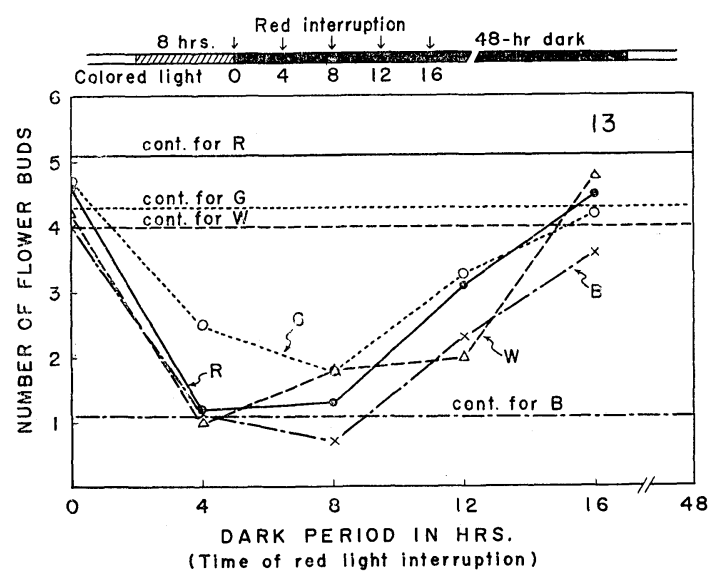

Fig. 13. Flowering responses to red light interruption applied at different times during the 8 hours of colored light and the subsequent 40 hour dark period $\left(20^{\circ}\right)$. Blue: $1000 \mu \mathrm{w} / \mathrm{cm}^{2}$, Green : $30 \mu \mathrm{w} / \mathrm{cm}^{2}$, Red : $12 \mu \mathrm{w} / \mathrm{cm}^{2}$, White : 30 $\mu \mathrm{w} / \mathrm{cm}^{2}$. Before exposure to colored light, plants were grown under 4000 lux of white light. period and for the reversion of the far-red effect, if the relative intensity was $1000: 30: 12: 30$. The experiments mentioned above suggested that the relative energy of each spectral region required to initiate the light-on and/or light-off rhythm is also similar to this ratio. To confirm this, two experiments were carried out. In one experiment, plants were subjected to 8 hours of darkness followed by 8 hours of blue, green, red, and white light of $1000,30,12$, and $30 \mu \mathrm{w} / \mathrm{cm}^{2}$, respectively. Then the plants were subjected to a 48-hour dark period $\left(21^{\circ}\right)$ and exposed to a 15-minute red light treatment at different times (Fig. 12). In other experiment, plants grown under 4000 lux of white light were subjected to the colored lights with the intensities mentioned above, for 8 hours followed by a 40-hour dark period at $20^{\circ}$. Fifteen minutes of red light was given during the colored light and the dark period at different times (Fig. 13).

In both experiments (Figs. 12 and 13), blue light was more inhibitory than others when no red light interruption was applied (control), but the flowering responses to red light interruptions were quite similar in all groups exposed to the different colors of light. This means that the flower inhibiting effect of the blue light (specific blue effect ${ }^{3)}$ ) was completely reversed by red light given in the dark period, and that blue, green, red, and white lights of $1000,30,12$, and $30 \mu \mathrm{w} / \mathrm{cm}^{2}$, respectively, were equally effective for induction of the light-off and/or lighton rhythms.

\section{References}

1) Takimoto, A. and Hamner, K.C., Plant Physiol. $39: 1024$ (1964). ibid. $40: 852$ (1965). $\quad 3$ ) , Bot. Mag. Tokyo $80: 213$ (1967).

2) $\longrightarrow$ and

4) - ibid. $79: 484$ 
(1966). 5) - Ikeda, K. and Imamura, S., ibid. $71: 317$ (1958).

6) and ibid. $72: 388$ (1959).

7) and ibid. 73 : 37 (1960).

\section{摘 要}

滝本 敦：アサガオの光周反応に関与寸る内生リズムの発現を支配する光条件

アサガオの花芽形成に関与する光周反応には二種の内生りズムが関与している1,2)． これら内生りズムの 発現を支配する光条件を調べて次の結果を得た.

8 時間の暗期後 5 分〜 2 時間の光照射を行い, 続いて 48 時間の主暗期を与光て主暗期中種々の時期に赤 色光による光中断を行うと，光中断の作用は最初に与えた 8 時間の暗期開始時に発現したリズムの支配をう ける. すなわち 5 分〜 2 時間の光 (4000 ルックス) は暗期開始時に発現したリズム (light-off rhythm) をあまり妨害せず，またそ机自身新しいリズムを発現さす能力を持たない。光照射時間を 4 8 時間にする 之最初の 8 時間暗期開始時に発現したリズムは消失し, この光が新しいリズムを誘発して主暗期中の赤色光 による光中断の作用は新しいリズムの支配を受ける. この場合, 新しいリズムを発現するのに必要な光の強 さは，わずか 70 ルックスであるが，照射時間が 2 時間以下の場合には 4000 ルックスの光を与えてる無効 である. 新しいリズムの発現には照射光の全エネルギー量よりも，むしろ照射時間が重要な意味をもつ.

リズムの発現に最も有効な光は赤色光であり, 青色光はかなり強い場合にの夕有効で, 近赤外光は無効で ある。

光（白色）の強さを 4000 ルックスから急激に 10 ルックスに減ずると，その時に light-off リズムが発現 する. 4000 ルックスから 250 ルックスへの減光はリズムを誘発し得ないが, 250 ルックスから暗黑への移行 はリズムを誘発し得る。

4000 ルックスの白色光から種々の強さの各種波長光に植物を移した場合, リズムの発現に必要な波長光 の強さ㤸色光で $1.5 \mu \mathrm{w} / \mathrm{cm}^{2}$ 以下, 白色, 緑色, 青色光では夫々 $4,5,20 \mu \mathrm{w} / \mathrm{cm}^{2}$ 以下である. 近赤外 光に移した場合には，近赤外光中でのリズムの進行が妨げられるらしく、リズムの発現は見られなかった。 (京都大学農学部応用植物学研究室) 